\title{
Influenza Virus-infected Dendritic Cells Stimulate Strong Proliferative and Cytolytic Responses from Human CD8 + T Cells
}

\author{
Nina Bhardwaj, ${ }^{*}$ Armin Bender, Noemi Gonzalez, Long Kim Bui, Maria C. Garrett, and Ralph M. Steinman \\ The Rockefeller University, and the *Hospital for Special Surgery, New York 10021
}

\begin{abstract}
Antigen-specific, CD8+, cytolytic T lymphocytes (CTLs) could potentially provide resistance to several infectious and malignant diseases. However, the cellular requirements for the generation of specific CTLs in human lymphocyte cultures are not well defined, and repetitive stimulation with antigen is often required. We find that strong CD8+ CTL responses to influenza virus can be generated from freshly isolated blood $T$ cells, as long as dendritic cells are used as antigen presenting cells (APCs). Small numbers of dendritic cells (APC:T cell ratio of 1:50-1:100) induce these CTL responses from most donors in $7 \mathrm{~d}$ of culture, but monocytes are weak or inactive. Whereas both dendritic cells and monocytes are infected with influenza virus, the former serve as effective APCs for the induction of $\mathrm{CD8}+\mathrm{T}$ cells while the latter act as targets for the CTLs that are induced. The strong CD8+ response to influenza virus-infected dendritic cells is accompanied by extensive proliferation of the CD8 + $T$ cells, but the response can develop in the apparent absence of CD4+ helpers or exogenous lymphokines. CD4+ influenza virus-specific CTLs can also be induced by dendritic cells, but the cultures initially must be depleted of CD8+ cells. These findings should make it possible to use dendritic cells to generate human, antigen-specific, CD8 + CTLs to other targets. The results illustrate the principle that efficient $T$ cell-mediated responses develop in two stages: an afferent limb in which dendritic cells are specialized APCs and an efferent limb in which the primed $T$ cells carry out an immune response to many types of presenting cells. ( $\mathrm{J}$. Clin. Invest. 1994. 94:797-807.) Key words: influenza virus • dendritic cells $\bullet \mathrm{CD8}+\mathrm{T}$ cells $\bullet$ cytotoxic $\mathrm{T}$ lymphocytes $\bullet$ vaccines
\end{abstract}

\section{Introduction}

The potential role of CD8+, cytolytic T lymphocytes ${ }^{1}$ (CTLs) in resistance to infectious and malignant diseases has been reem-

Address correspondence to Nina Bhardwaj, Laboratory of Cellular Physiology and Immunology, The Rockefeller University, 1230 York Avenue, New York, NY 10021.

Received for publication 21 January 1994.

1. Abbreviations used in this paper: APC, antigen presenting cells; CTL, cytolytic T lymphocytes; ER+, T cell enriched; ER-, T cell depleted; HA, hemagglutinin; HRP, horseradish peroxidase; LCMV, lymphocytic choriomeningitis virus; MLR, mixed leukocyte reaction; NK, natural killer cells; NP, nucleoprotein; PE, phycoerythrin.

J. Clin. Invest.

(C) The American Society for Clinical Investigation, Inc.

0021-9738/94/08/0797/11 \$2.00

Volume 94, August 1994, 797-807 phasized by recent developments. Antigen-specific CTLs are recognized as a possible defense mechanism in infection with HIV-1 (1-3), cytomegalovirus (4), and in malaria (5). Antigens that are recognized by melanoma-specific CTLs have also been identified by Van der Bruggen et al. (6) and Brichard et al. (7). These studies document the specificity of CTLs that recognize clinically important targets. Less is understood about the initial generation of these CTLs, however.

As in most $\mathrm{T}$ cell responses, the precursors for active CTLs are quiescent lymphocytes that must be induced to expand clonally and develop effector functions. For CTL activation to occur, not only must antigens be presented as peptide fragments on MHC products, but the antigen-MHC complexes must also be introduced on cells with the requisite accessory functions that lead to $\mathrm{T}$ cell growth and cytolytic activity. There is evidence, primarily from the studies of killer cells to transplantation antigens, that an effective way to induce human CTLs is to present antigens on dendritic cells (8). Dendritic cells are specialized accessory cells for the initiation of many $\mathrm{T}$ cell-dependent immune responses (for review see reference 9).

Here we have used dendritic cells to stimulate virus-specific CTLs from human blood. The model we chose to study was influenza. Improved mechanisms for prophylaxis and therapy are needed in influenza, because control of the respiratory infection is not readily achieved through current approaches to vaccination. For example, presently available vaccines are not designed to induce killer cells but instead boost antibody responses to viral antigens that undergo antigenic drift and shift (10). It is known that dendritic cells are a component of the alveolar septae and airway epithelium of the lung $(11,12)$ and that the appearance of influenza virus-specific CTLs is associated with a more rapid clearance of virus from nasal washings (13). Influenza virus is also the agent used to dissect the different pathways for antigen presentation and analyze the specificity of CTLs. Townsend and associates $(14,15)$ realized that viral proteins were processed in the cytoplasm and presented as peptides in association with class I MHC products of the infected cell. Morrison et al. (16) used influenza virus to distinguish the two pathways for antigen presentation to CTLs. One emanates from acidic endocytic vesicles and leads to presentation on $\mathrm{MHC}$ class II to CD4+ CTLs; the other emanates from a nonacidic biosynthetic compartment for presentation on MHC class I to CD8+ CTLs. The CTLs that have been the subject of work in humans are usually generated from unseparated blood mononuclear cells and/or repeated stimulation of responding lymphocytes with exogenous IL-2 and viral antigens $(4,5,13,14,17-$ 22). For example, Carreno et al. (17) used repeatedly stimulated human blood cells in their elegant mapping studies of influenza peptides that are presented to CTLs. In this study, we identify an effective accessory cell system to generate human influenzaspecific killer cells.

We show that influenza A virus establishes a nontoxic infec- 
tion of human dendritic cells and that these infected dendritic cells induce the development of strong virus-specific CTLs within $7 \mathrm{~d}$. Three features of the response will be stressed: both strong CD8 $+\mathrm{T}$ cell proliferation as well as CTL activity are evident, the killer cells once generated recognize and kill infected MHC class I-matched monocytes, and no exogenous cytokines or CD4+ helpers are required.

\section{Methods}

\section{Culture medium}

RPMI 1640 (Gibco Laboratories, Grand Island, NY) supplemented with $100 \mu \mathrm{g} / \mathrm{ml}$ gentamicin, $5 \%$ human serum, and $10 \mathrm{mM}$ Hepes buffer.

\section{Blood mononuclear cells}

In most experiments, buffy coats served as sources of PBMCs and were obtained from the New York Blood Center (New York, NY). Blood donors were also healthy volunteers who were HLA typed and selected for MHC class I mismatch. PBMCs were separated into T cellenriched $(\mathrm{ER}+)$ and $\mathrm{T}$ cell-depleted fractions (ER-) as previously described (23).

$T$ cells. ER + cells were first depleted of monocytes by panning on dishes coated with human gamma globulin (24). MHC class II+ and natural killer $(\mathrm{NK})$ cells $(\mathrm{CD} 16+$ and $\mathrm{CD} 11 \mathrm{~b}+)$ were depleted by coating with mAbs 9.3C9 (ATCC; HB180), and 3G8 (gift of Dr. Jay Unkeless) and OKM1 (ATCC;CRL 8026), respectively, followed by panning on petri dishes coated with goat anti-mouse IgG (8). The resulting $\mathrm{T}$ cell population contained $<2-3 \%$ of contaminating MHC class II+ and NK cells, as monitored by cytofluorography. In some experiments, $\mathrm{T}$ cells were enriched for CD4+ or CD8 + cells by incubation with Leu 2 or Leu $3 \mathrm{mAbs}$, respectively, followed by panning as above. CD4 + and CD8 + cells were $>95 \%$ pure when evaluated by staining with PE-conjugated Leu 2 or Leu 3 (Becton Dickinson \& Co., Mountain View, CA), both before and after the culture period that was used to generate influenza responses.

APC populations. Monocytes were obtained from ER - cells by adhering them onto plastic dishes for 60-90 min and dislodged by pipetting. Nonadherent cells were subsequently used for purification of B cells and dendritic cells, as described previously $(24,25)$. Residual monocytes were first removed by panning on gamma globulin-coated plates (24). The ER-, FcR - cells proved to be adequately enriched in the dendritic cells that are needed as APCs for strong CTL responses. However, to further enrich the dendritic cells, and the potency of the APCs, ER-, FcR - cells were layered onto $14 \%$ metrizamide gradients (25). After sedimentation, dendritic cells localize to the low density interface, whereas B cells and NK cells are enriched in the high density interface. Dendritic cell purity was $50-70 \%$ with contaminants being $B$ cells, NK cells, and a few T cells.

\section{Virus preparation}

Influenza virus strain PR8 (A/Puerto Rico/8/34) was kindly provided by Dr. Peter Palese (Mount Sinai School of Medicine, New York) in the form of infectious allantoic fluid. Virus was grown up and purified as previously described (26). Virus stocks were replenished from seed virus by Spafas Inc. (Storrs, CT) and stored in liquid nitrogen (virus stock: 20,000 HAU/ml). Virus titers were determined using a hemagglutination assay, as previously described (26).

\section{Infection of cells}

APCs and target cells were washed out of medium containing serum and resuspended in RPMI at $0.5-1 \times 10^{7}$ cells $/ \mathrm{ml}$. Virus was added at a final concentration of 1,000 HAU PR8/ml and incubated for $60 \mathrm{~min}$ at $37^{\circ} \mathrm{C}$. This dose is saturating for the induction of influenza-specific CTLs. To determine whether influenza infection proceeded through an acidic compartment in APCs, the cells were incubated in $10 \mathrm{mM} \mathrm{NH}_{4} \mathrm{Cl}$ for $30 \mathrm{~min}$ before adding virus and throughout the subsequent infection.
In some cases, the $\mathrm{NH}_{4} \mathrm{Cl}$ was added throughout the culture period, which was generally $24 \mathrm{~h}$.

\section{Induction of influenza-specific CTL}

$1 \times 10^{6}$ purified $\mathrm{T}$ cells were cultured in 24-well plates (Costar, Cambridge, MA) with graded doses of influenza virus-infected or uninfected APCs, in a total volume of $1.1 \mathrm{ml}$. After $7 \mathrm{~d}$ of culture, the cells were harvested and distributed in varying numbers to 96 -well microtiter plates [100 $\mu \mathrm{l}$ per well]. CTL activity was measured using a ${ }^{51} \mathrm{Cr}$-release assay with infected or uninfected syngeneic monocytes as targets. $1 \times 10^{4}$ targets in a volume of $50 \mu \mathrm{l}$ were added to each well to generate E:T ratios ranging from $1: 1$ to $100: 1$.

\section{${ }^{51} \mathrm{Cr}$ release assay}

Monocytes were obtained from ER - cells by adhering them onto plastic dishes for 60-90 min and dislodged by pipetting. $1 \times 10^{7}$ monocytes were cultured in $10 \mathrm{ml}$ volumes in 60-ml Teflon beakers (Savillex Corp., Minnetonka, MN) until use as targets in the CTL assay (27). For ${ }^{51} \mathrm{Cr}$ labeling and infection, cells were collected on ice, washed free of serum, and brought up to $1 \times 10^{7} / \mathrm{ml}$ in RPMI. $400 \mu \mathrm{Ci} \mathrm{Na}{ }^{51} \mathrm{CrO}_{4}(1 \mathrm{mCi} / \mathrm{ml}$ sterile stock; New England Nuclear, Boston, MA) was added per 1 $\times 10^{7}$ monocytes. They were simultaneously infected with $1,000 \mathrm{HAU}$ $\mathrm{PR} 8 / \mathrm{ml}$ for $1 \mathrm{~h}$ at $37^{\circ} \mathrm{C}$. The targets were washed four times and resuspended at $2 \times 10^{5} / \mathrm{ml}$, after which $50 \mu \mathrm{l}$ was aliquoted to each well containing effector $\mathrm{T}$ cells. Spontaneous and total release samples were prepared by adding the targets to wells containing RPMI alone or a final concentration of $0.33 \%$ SDS, respectively. The plates were centrifuged for $2 \mathrm{~min}$ at $15 \mathrm{~g}$ and incubated for $5 \mathrm{~h}$ at $37^{\circ} \mathrm{C}$. At the termination of the assay, the supernatant was collected with absorption cartridges using a harvesting press (Skatron Instruments Inc., Sterling, VA) and counted in a gamma counter. Percent specific ${ }^{51} \mathrm{Cr}$ release was calculated from the following formula: $100 \times[$ [Release by CTL - spontaneous release $) /($ Total release - spontaneous release $)]$. Spontaneous release was $15-25 \%$ of the total release.

\section{FACS analysis of cell populations and cell sorting}

After culture with uninfected or virus-infected APCs, T cells were phenotyped by staining with Simultest CD4-FITC/CD8-PE or Simultest control (Becton Dickinson) and analyzed on a FACScan (Becton-Dickinson). In some experiments, $\mathrm{T}$ cells were separated into $\mathrm{CD} 4+$ and CD8 + subsets by sorting on a FACStar Plus (Becton Dickinson). $1 \times 10^{7}$ cells were stained with $20 \mu$ of Simultest CD4-FITC/CD8PE (Becton Dickinson) for $45 \mathrm{~min}$ at $4^{\circ} \mathrm{C}$, washed three times, and sorted. CD4+ cells were collected as FITC + cells whereas CD8+ cells were PE +. Contamination of CD4+ cells with CD8 + cells or vice versa was $<1 \%$. Sorted populations were stained again after a period of $7 \mathrm{~d}$ and did not demonstrate any change in their CD4/CD8 phenotype. The antibodies did not appear to block function because purified populations could respond to influenza virus-infected APCs (see Results).

\section{Detection of influenza virus infection by immunohistochemistry}

Cytospins of various cell populations were prepared using a Cytospin 2 centrifuge (Shandon, Inc., Pittsburgh, PA). Slides were fixed in acetone for $5 \mathrm{~min}$ at room temperature and then incubated in hybridoma supernatant for $45 \mathrm{~min}$. The mAbs to influenza virus proteins were kindly provided by Dr. J. Yewdell, National Institutes of Health, and included anti-NP (H16-L10-4R5; ATCC HB65) and anti-HA (H28E23 and H17L2). The cytospins were washed several times with PD/1\% BSA, and incubated with 1:200 dilution of biotinylated goat anti-mouse Ig (Boehringer Mannheim Biochemicals, Indianapolis, IN), for $45 \mathrm{~min}$, followed by a horseradish peroxidase (HRP)-biotin-avidin complex (ABC kit; Vector Laboratories, Inc., Burlingame, CA) for $30 \mathrm{~min}$. Nonbound HRP was then washed off, and the HRP reaction product was developed with $\mathrm{H}_{2} \mathrm{O}_{2}$ and diaminobenzidine tetrahydrochloride (Polysciences, Warrington, PA). 


\section{Lymphocyte proliferation assay}

After infection with influenza virus, APCs were added in graded doses to $1 \times 10^{5} \mathrm{~T}$ cells in 96-well flat-bottomed plates (Costar). Uninfected APCs served as controls. Proliferation was determined on days 5-6 with the addition of $4 \mu \mathrm{Ci} / \mathrm{ml}$ of $\left[{ }^{3} \mathrm{H}\right] \mathrm{TdR}$ for $12-16 \mathrm{~h}$ to triplicate microwells (mean cpm).

\section{Results}

Influenza virus uptake and infection in human dendritic cells. There is considerable evidence, primarily in mouse cell cultures, that dendritic cells effectively present viral antigens to $\mathrm{T}$ cells $(26,28-30)$. Murine dendritic cells can be infected by influenza virus and elicit potent CTL responses $(26,29)$. The responses are dependent upon the synthesis of endogenous viral proteins (26). We wished to determine the extent to which human dendritic cells could be infected with influenza virus. Dendritic cells were isolated from buffy coat preparations as previously described and pulsed with live influenza virus for $1 \mathrm{~h}$ in serumfree medium. After multiple washes, immunohistochemistry was used to detect two viral proteins, NP and HA, within the cell, from 1 to $16 \mathrm{~h}$ after infection (Fig. 1). In addition, dendritic cells were compared with macrophages isolated from the same donor.

Dendritic cells failed to stain with isotype-matched antibody OKT8 (Fig. $1 A$ ) but stained intensely with mAb to MHC class II (Fig. $1 B$ ). At $16 \mathrm{~h}$ after infection, NP staining was primarily localized to the nucleus of dendritic cells, although there was clearly a cytoplasmic distribution in addition (Fig. $1 C$ ). A diffuse distribution of HA, consistent with endogenous viral protein synthesis, was evident (Fig. 1, $D$ and $E$ ). Greater than $90 \%$ of the dendritic cells were infected by these criteria, with a viability of $>90 \%$. The NP and HA patterns of staining at $16 \mathrm{~h}$ after infection indicate extensive synthesis of viral proteins in the dendritic cells. Uninfected dendritic cells did not stain with any mAbs for viral-specific proteins (data not shown).

After just $1 \mathrm{~h}$ of infection, dendritic cells expressed HA primarily in a granular pattern, suggesting that the virus is first contained within endocytic vacuoles (Fig. $1 F$ ). Evidence of viral protein synthesis was also apparent in that there was diffuse cytoplasmic staining of a few cells at this early time point (Fig. $1 F$, black arrows). Pretreatment of dendritic cells with $\mathrm{NH}_{4} \mathrm{Cl}$ before, during, and after a virus pulse blocked infection, i.e., few cells $(<2 \%)$ stained with either anti-HA or anti-NP mAbs (data not shown). These findings confirm that influenza requires an acidic compartment to deliver its genome to the cytoplasm and engage in viral-specific protein synthesis. Macrophages were also highly susceptible to infection with influenza. The degree of infection was generally $>70 \%$ (Fig. 1, $G$ and $H$ ). After overnight incubation following infection, many cells died and appeared to be phagocytosed by viable macrophages (Fig. $1 \mathrm{G}$, black arrow). In contrast, dendritic cells showed no change in viability for up to $2 \mathrm{~d}$ after infection.

Lymphocytes also were examined by immunolabeling for their ability to be infected by influenza virus, but none appeared to be as infected as dendritic cells. B cells and T cells were not susceptible to infection as assessed by staining with anti-HA and NP mAbs. T cell blasts generated with superantigens had a low level of infection (10-30\% of the total T cell preparation), whereas EBV-transformed cells had weak staining in 10-30\% of the cells.
Relative efficacy of different influenza virus-pulsed APCs to induce $T$ cell proliferative responses. Enriched populations of different APCs were pulsed with live influenza virus, and their ability to stimulate $\mathrm{T}$ cell proliferation was assessed. Viruspulsed dendritic cells were 30-50-fold more effective than macrophages and $>200$-fold more effective than B cells (Fig. 2). Influenza-specific responses were detectable even when one dendritic cell was used per $300 \mathrm{~T}$ cells. At these stimulator/ responder ratios, influenza virus-pulsed macrophages and $B$ cells were unable to induce $\mathrm{T}$ cells to proliferate (Fig. 2). We noted that in cultures containing significant numbers of infected macrophages, e.g., at T cell/APC ratios of 10:1 or bulk cultures of PBMCs, there was striking toxicity and death of most cells, including $\mathrm{T}$ cells.

Dendritic cells are potent stimulators for the induction of influenza-specific killer cell responses. We compared dendritic cells and macrophages for their capacity to generate human virus-specific CTL responses. The responding $\mathrm{T}$ cells were extensively depleted of APCs and added at a constant dose of $1 \times 10^{6}$ (see Methods). APCs were then added in graded doses. In dozens of experiments, the $\mathrm{T}$ cells never generated lytic activity unless APCs were added, and the APCs themselves did not form lytic cells. Dendritic cells, if infected with influenza virus, generated significant CTL responses even when used at a 100:1 T cell/dendritic cell ratio (Fig. 3 A). Significant killing was seen in the primary effector cell populations even at $E / T$ ratios of 10:1 (Fig. $3 \mathrm{~B}$ ) or less (data not shown). In contrast, macrophages were far less stimulatory, in the order of 100fold or less, possibly due to the significant macrophage death observed after infection with virus. Since B cells are poor stimulators of the proliferative response to influenza and do not get infected with the virus (see above), it is unlikely that contaminating $B$ cells in our dendritic cell population account for the CTL that are generated. OKM1, an mAb directed towards the CD1 1b antigen, known to remove NK cell precursors (8), was used to deplete these cells from the starting $\mathrm{T}$ cell population. Thus, the effector cell population used in these assays is composed of $\mathrm{T}$ cells. Experiments to be described below showed the killers to be $\mathrm{CD} 8+\mathrm{CD} 4-$. Most donors, $>90 \%$, could be stimulated to form CTLs with virus-infected dendritic cells, indicating that the majority of our donor pool has been exposed to influenza. Because CTL activity was measured on influenza A/PR8-infected targets, a strain first identified in 1934, and the prevalent strains are $A / T$ exas/36/91 and A/Beijing/32/92, the CTLs generated appear to be cross-reactive, confirming other studies of human influenza-specific CTLs (18).

Knowing that B cells do not contribute to CTL development, we next determined whether a partially purified preparation of dendritic cells (i.e., omitting the metrizamide column for enrichment) was adequate for generating CTL responses to influenza. ER - , FcR - preparations are depleted of most $\mathrm{T}$ cells and monocytes and consist of $\sim 5 \%$ dendritic cells, the remaining cells being primarily B cells. At T/APC ratios of 3:1 or 10:1, significant CTL responses were apparent (Fig. 4). This corresponds to a T/dendritic cell ratio of $60: 1$ to $\sim 180: 1$. ER - , FcR - cells were used as stimulators for all subsequent experiments, in T/APC ratios varying from 3:1 to 5:1. These partially enriched populations (a) suffice to provide the cultures with dendritic cells in the $0.5-1.5 \%$ range, $(b)$ lack inhibitory monocytes, and $(c)$ are straightforward to prepare.

To ascertain when lytic activity was optimal, we measured 

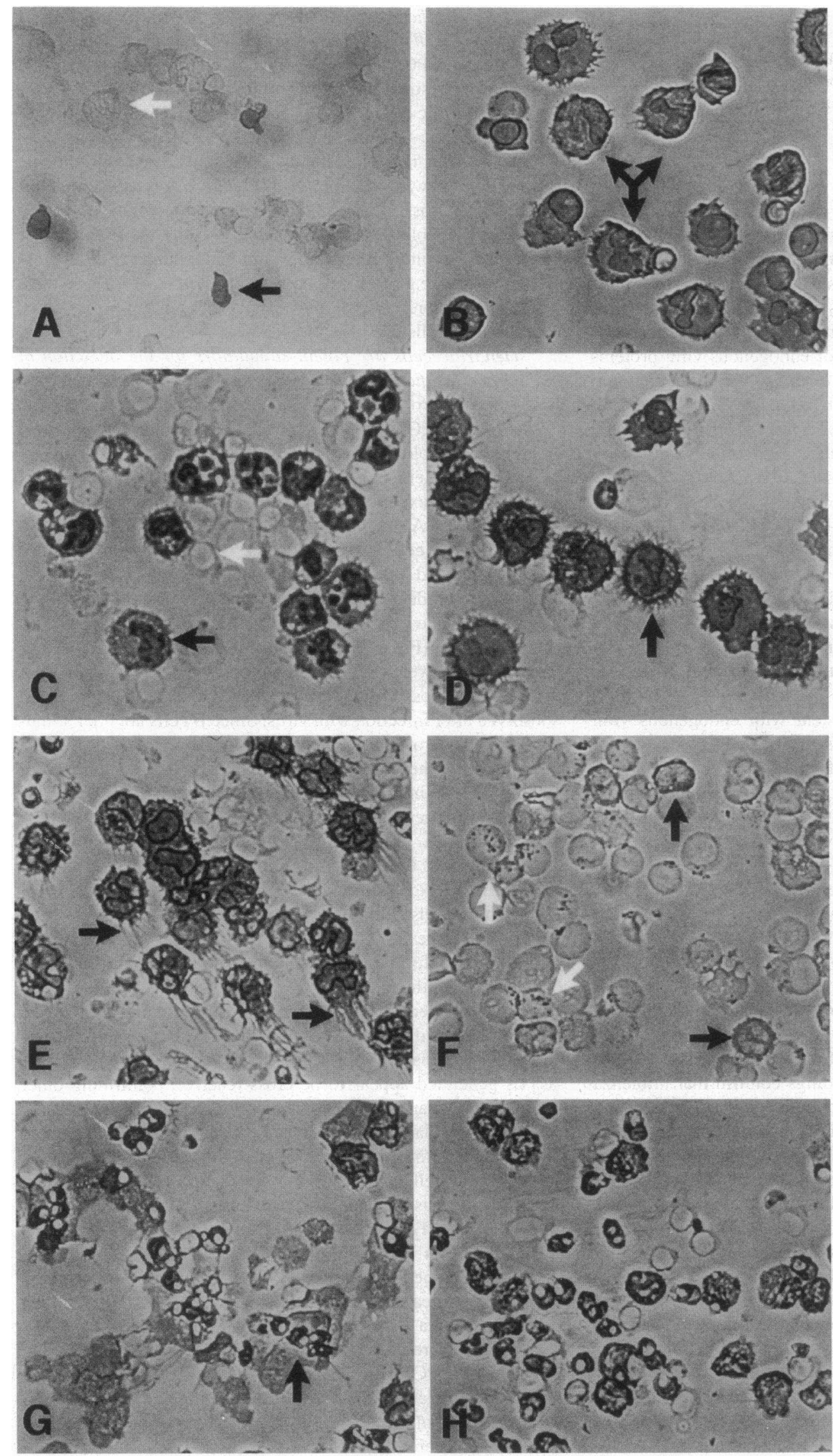

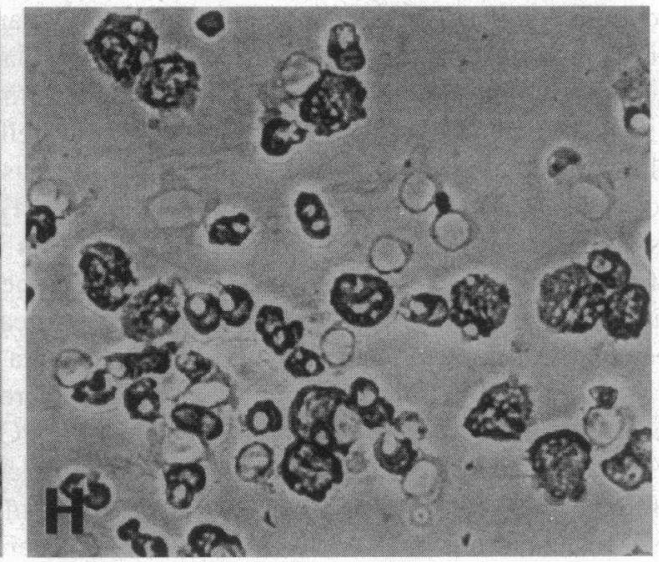

Figure 1. Following infection with influenza virus, dendritic cells express $\mathrm{HA}$ and NP proteins. $(A-E)$ Dendritic cells were pulsed with virus for $60 \mathrm{~min}$, washed extensively, and then cultured for $16 \mathrm{~h} .(F)$ Dendritic cells were cultured for $1 \mathrm{~h}$ after the virus pulse. ( $G$ and $H$ ) Purified monocytes were infected with influenza virus as above and cultured for $16 \mathrm{~h}$. At the end of the culture period, cells were collected and cytospins were prepared and stained with the following panel of $\mathrm{mAbs}$ :

(A) Control mAb, anti-CD8 (OKT8) Black arrows depict contaminating

$\mathrm{CD} 8+\mathrm{T}$ cells in the APC population. A white arrow illustrates a negatively stained dendritic cell. (B) Anti-MHC class II (9.3C9). The three-headed arrow identifies typical dendritic cells. $(C)$ Anti-NP (HB65). The black arrow points to the intense nuclear location of NP in a dendritic cell. The white arrow illustrates a negatively stained contaminating lymphocyte. (D) Anti-HA (H17L2). The arrow points to a typical dendritic cell. $(E-G)$ Anti-HA (H28E23). In $E$, the arrows identify typical dendritic cells, with hairy processes as expected for a plasma membrane envelope protein. In $F$, white arrows point to the granular appearance of HA presumably in endosomal granules; black arrows point to the diffuse location of HA in a few rapidly infected dendritic cells. In $G$, dying infected monocytes are phagocytosed by noninfected cells (black arrow). $(H)$ Anti-NP (HB65). NP is detected in several dying and live monocytes. 


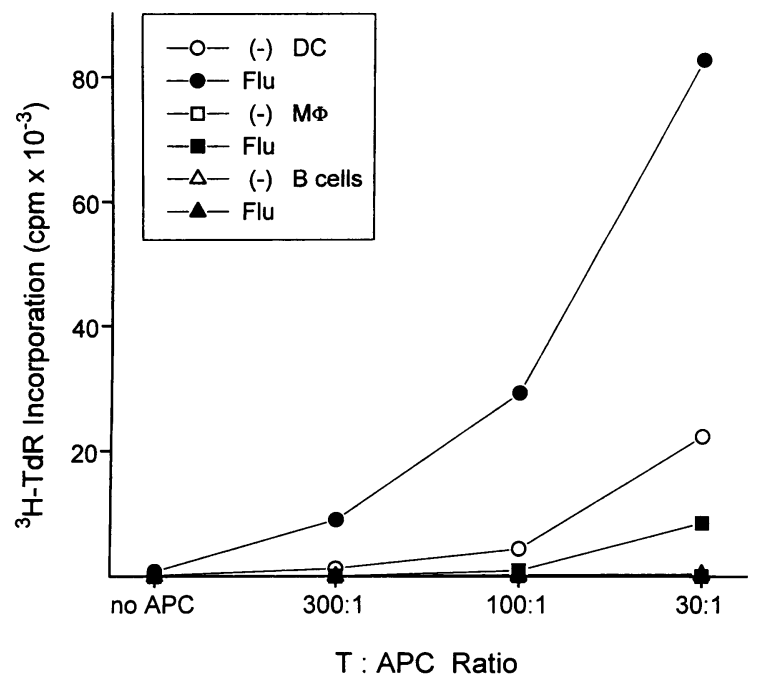

Figure 2. Influenza virus-infected dendritic cells stimulate $\mathrm{T}$ cell proliferative responses. Bulk $\mathrm{T}$ cells were tested in a standard proliferation assay for responsiveness to influenza virus-infected and noninfected dendritic cells, macrophages, and B cells at various T/APC ratios. Cultures were pulsed on day 5 for $9 \mathrm{~h}$ with $4 \mu \mathrm{Ci} / \mathrm{ml}$ of $\left[{ }^{3} \mathrm{H}\right] \mathrm{TdR}$. Results are means of triplicates.

CTL development over the course of $9 \mathrm{~d}$. Lytic activity peaked at day 7 (Fig. 5), consistent with other studies (18) with little variation from donor to donor. At this time, microscopic examination routinely showed the development of large cell clusters and released $\mathrm{T}$ cell blasts, as is characteristic of dendritic cellmediated $\mathrm{T}$ cell responses in vitro (9). Occasionally, assays were done on day 8 if the clusters seemed slow to develop, and blast release was delayed.

CD8+ T cells are the principal CTLs induced with infected dendritic cells. To establish the types of influenza-specific effector cells in our system, we stimulated bulk $T$ cells with

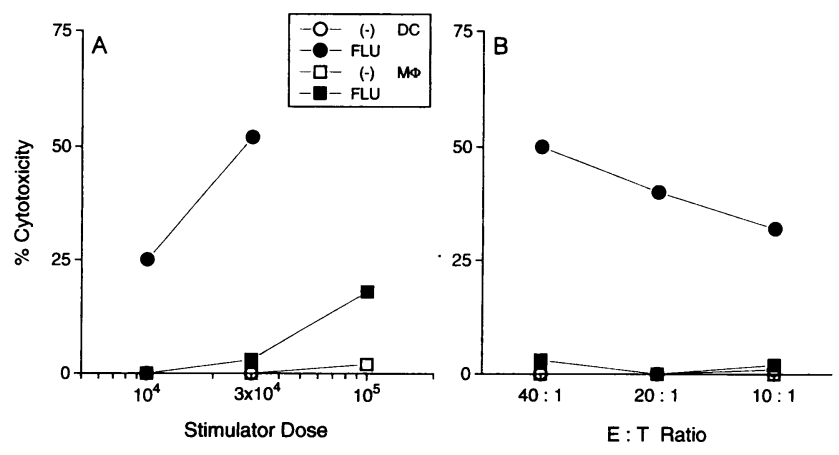

Figure 3. Dendritic cells are potent stimulators for the induction of influenza-specific CTL responses. $(A) 1 \times 10^{6}$ purified T cells from buffy coat donors were stimulated with graded doses of uninfected (open symbols) or influenza virus-infected (closed symbols) dendritic cells or monocytes. After $7 \mathrm{~d}$, CTL activity was measured using infected syngeneic monocytes as targets at E/T ratio of 40:1. Lysis of uninfected target cells was $<5 \%$ at all doses of stimulators used (not shown). (B) Purified $\mathrm{T}$ cells were cultured with uninfected or infected dendritic cells or monocytes at T/APC ratios of 30:1 for $7 \mathrm{~d}$. Lytic activity was measured on syngeneic monocyte targets at various $\mathrm{E} / \mathrm{T}$ ratios, as shown. Lysis of uninfected target cells was $<5 \%$ at all $\mathrm{E} / \mathrm{T}$ ratios used (not shown).

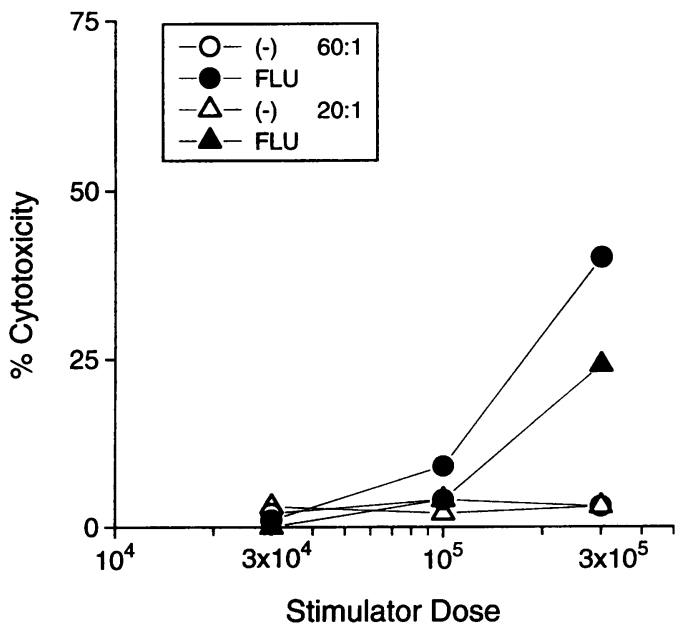

Figure 4. Partially enriched preparations of dendritic cells suffice as stimulators of influenza-specific CTL responses. $1 \times 10^{6}$ purified T cells were cultured with graded doses of uninfected (open symbols) or infected ER-, FcR- cells comprising $\sim 5 \%$ dendritic cells (closed symbols). Lytic activity was measured on syngeneic targets on day 7 of culture at $\mathrm{E} / \mathrm{T}$ ratios of 60:1 and 20:1. Lysis of uninfected target cells was $<5 \%$ at all stimulator doses and $\mathrm{E} / \mathrm{T}$ ratios used.

infected dendritic cells for $7 \mathrm{~d}$ and then separated the populations into CD4+ and CD8+ subsets. The cultures were stained with CD4-FITC and CD8-PE mAbs (see Methods) and sorted on a FACStar into $>98 \%$ pure CD4+ and CD8+ populations. Unseparated as well as sorted cells were then evaluated for lytic activity. Table I shows the data from three individual experiments. Influenza-specific lytic activity was seen in two populations: bulk $\mathrm{T}$ cells and purified CD8 $+\mathrm{T}$ cells. $\mathrm{CD} 4+\mathrm{T}$ cells failed to demonstrate any lytic activity. In general the CD8+ cells were enriched for lytic activity compared with the bulk $T$ cells (experiments 1 and 2). FACS analyses of the stimulated cultures contained many enlarged $\mathrm{T}$ blasts and most of the enlarged cells were CD8+; few CD4+ cells appeared to enlarge in these cultures (Fig. 6).

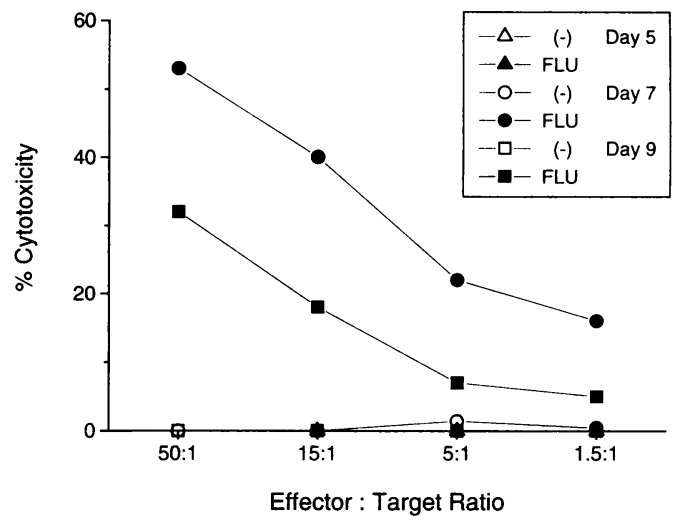

Figure 5. Kinetics of CTL development. Purified T cells obtained from a buffy coat donor were stimulated with partially enriched populations of uninfected (open symbols) or influenza virus-infected (closed symbols) dendritic cells at T/APC ratios of 3:1. Lytic activity was measured at day 5,7 , or 9 on infected syngeneic monocyte targets. Lysis of uninfected monocyte targets was $<5 \%$ at all time points assayed. 
Table I. Influenza Virus-specific CTL in Bulk Cultures Are CD8+CD4-

\begin{tabular}{|c|c|c|c|c|c|c|c|}
\hline \multirow[b]{3}{*}{$\begin{array}{l}\text { Responding } \\
\text { T cells }\end{array}$} & \multirow[b]{3}{*}{$\begin{array}{l}\text { Infection } \\
\text { of APCs }\end{array}$} & \multicolumn{6}{|c|}{ Percent specific lysis of macrophage targets } \\
\hline & & \multicolumn{2}{|c|}{ Experiment 1} & \multicolumn{2}{|c|}{ Experiment 2} & \multicolumn{2}{|c|}{ Experiment 3} \\
\hline & & $\begin{array}{l}\mathbf{M \phi} \\
(-)\end{array}$ & $\begin{array}{l}\text { M } \phi \\
\text { Flu }\end{array}$ & $\begin{array}{l}\mathbf{M} \phi \\
(-)\end{array}$ & $\begin{array}{l}\text { M } \phi \\
\text { Flu }\end{array}$ & $\begin{array}{l}\mathrm{M} \phi \\
(-)\end{array}$ & $\begin{array}{l}\text { M } \phi \\
\text { Flu }\end{array}$ \\
\hline \multirow[t]{2}{*}{ Bulk } & $(-)$ & 0 & 0 & 0 & 0 & 2 & 4 \\
\hline & Flu & 0 & 25 & 0 & 42 & 9 & 51 \\
\hline \multirow[t]{2}{*}{$\mathrm{CD}^{+}$} & $(-)$ & 0 & 0 & 0 & 0 & 4 & 8 \\
\hline & Flu & 0 & 0 & 0 & 0 & 4 & 9 \\
\hline \multirow[t]{2}{*}{$\mathrm{CD}^{+}$} & $(-)^{*}$ & 3 & 7 & 0 & 0 & 3 & 9 \\
\hline & Flu & 2 & 37 & 0 & 57 & 16 & 54 \\
\hline $\mathrm{E} / \mathrm{T}$ ratio & & \multicolumn{2}{|c|}{$40: 1$} & \multicolumn{2}{|c|}{$40: 1$} & \multicolumn{2}{|c|}{$50: 1$} \\
\hline
\end{tabular}

Purified $T$ cells were stimulated with partially enriched populations of uninfected or influenza virus-infected dendritic cells at T/APC ratios of 3:1. After $7 \mathrm{~d}$ of culture, the T cells were stained with CD4-FITC and CD8-PE mAbs and sorted on a FACStar Plus. The CD4+ and CD8 + populations were $>98 \%$ pure. Lytic activity of each population was measured on infected syngeneic monocyte targets. Uninfected dendritic cells failed to stimulate influenza specific CTL. Three individual experiments are shown. ${ }^{*}$ In experiment 1 , the $\mathrm{E} / \mathrm{T}$ ratio in the CD8+ $\mathrm{T}$ cell group was 30:1.

To ascertain whether dendritic cell-induced CD8+, influenza-specific CTLs were class I restricted, we evaluated responses generated in two individuals who differed at class I loci but shared class II specificities (DRw52, DQw1). Donor A demonstrated significant lytic activity against syngeneic infected macrophage targets (Fig. 7) but lesser activity against class I mismatched targets (donor B macrophage targets). Likewise, donor $B$ effector cells lysed syngeneic but not allogeneic (donor A) targets. The small degree of cross-reactivity seen in the case of A effectors versus B targets may be due to unspecified but shared class I antigens or, possibly, the development of CD4+-mediated CTL activity, which has been described in cloned human populations $(31,32)$. However, the latter is less likely given that no CD4+ CTLs are generated in our system (see below).

Purified CD4+ and CD8+ $T$ cells respond to influenza virus-infected dendritic cells. The observation that few CD4+ T cells seemed to be undergoing proliferation was surprising, since their role as helper cells for influenza virus-specific CTL responses is evident in mouse cultures (26). Also human CD4+ $\mathrm{T}$ cell clones with lytic activity have been described $(31,32)$. To determine whether CD4+ $\mathrm{T}$ cells could respond to influenza virus-infected APCs, we used cell sorting to purify CD4+ and CD8 $+\mathrm{T}$ cells before $\mathrm{T}$ cell stimulation. Bulk, sorted CD4+, or CD8 + $\mathrm{T}$ cells, and a combination of both sorted populations were tested in a standard proliferation assay for responsiveness to influenza virus-infected ER-, FcR - cells. All four groups were able to mount proliferative responses to these APCs (Fig. 8). The most prominent response was demonstrated by the CD8 + T cells (note the lower background) compared with either bulk or CD4+ T cells. The extent of these responses were generally similar at several time points tested.
When CTL responses from these populations were measured, two striking observations were made. First, sorted CD8+ T cells developed CTL activity without a requirement for CD4+ $T$ cells (Fig. 9). These observations are reminiscent of human alloreactive responses, in which CD4+ helper cells are not required for the generation of CD8 + CTL if dendritic cells are the APCs (8). Second, CD4+ T cells also developed lytic activity, but only in the absence of CD8 + T cells. We confirmed that the sorted populations were $>98 \%$ pure at the termination of the 7-d induction period. Thus, contamination of the CD8+ $T$ cells with CD4 $+T$ cells, or vice versa, does not account for these results. It is more likely that CD4+ $\mathrm{T}$ cells only exhibit the capacity to become CTLs when few or no CD8 $+\mathrm{T}$ cells are present.

\section{Discussion}

Experimental conditions for the generation of human CD8+ CTLs. To generate CD8+ CTLs against infectious agents in cultures of human $\mathrm{T}$ cells, one commonly uses unseparated populations of PBMCs and/or repeated stimulation in the presence of exogenous lymphokines such as IL-2 $(4,5,13,14,17-$ 22). These requirements for CD8+ CTL development stand in contrast to CD4+ $\mathrm{T}$ cell responses, which often are detected within 3-5 d of culture without exogenous lymphokines. Furthermore, the primary APCs that induce CTL responses in human $T$ cell cultures have not been well characterized. We report here that strong influenza virus-specific CTLs can be induced using virus-infected dendritic cells as APCs. Partially enriched dendritic cells, which are straightforward to isolate, suffice for the development of CTLs. Our data extend prior reports that human dendritic cells can induce proliferative $\mathrm{T}$ cell responses to influenza virus (33).

Four features distinguish our system for generating CTLs from the bulk culture systems that have been used previously. First, only a few dendritic cells (0.5-1\% suffice) are able to generate highly potent CTL; as demonstrated by the fact that killing is evident at $\mathrm{E} / \mathrm{T}$ ratios of 1.5:1 (Fig. 5). Such efficacy has not been described in CTLs generated from cultures of bulk PBMCs $(13,14,18,21)$. Second, depletion of monocytes is necessary to remove potential inhibitory and toxic effects on the effector cells. In attempts to generate CTLs from unseparated PBMCs, we often observed significant cell death that prohibited killer cell development. This was likely secondary to cytopathic effects of viral infection in monocytes (Fig. 1), as previously described $(34,35)$. PBMCs contain about $1 \%$ dendritic cells (36), and an Ia + cell is known to be required for the generation of influenza virus-specific CTL in bulk PBMC culture systems (18). We suggest that these small numbers of dendritic cells are sufficient to permit CTL development in circumstances where few monocytes are present or become infected. Third, although monocytes do not induce CTLs effectively, they serve as efficient targets in short-term chromium-release assays $(5 \mathrm{~h})$. During this time interval, a majority of monocytes express viral proteins as demonstrated by immunohistochemistry (data not shown). In contrast, standard target cells, e.g., B cell lines or PHA-treated lymphocytes, have a low level of infection (10$30 \%$ ) and are less efficient in our hands as targets. Fourth, effector cell populations are routinely depleted of NK cells. These cells, which are activated by dendritic cells in vitro to lyse tumor cell targets (8), may play a role in viral clearance. 

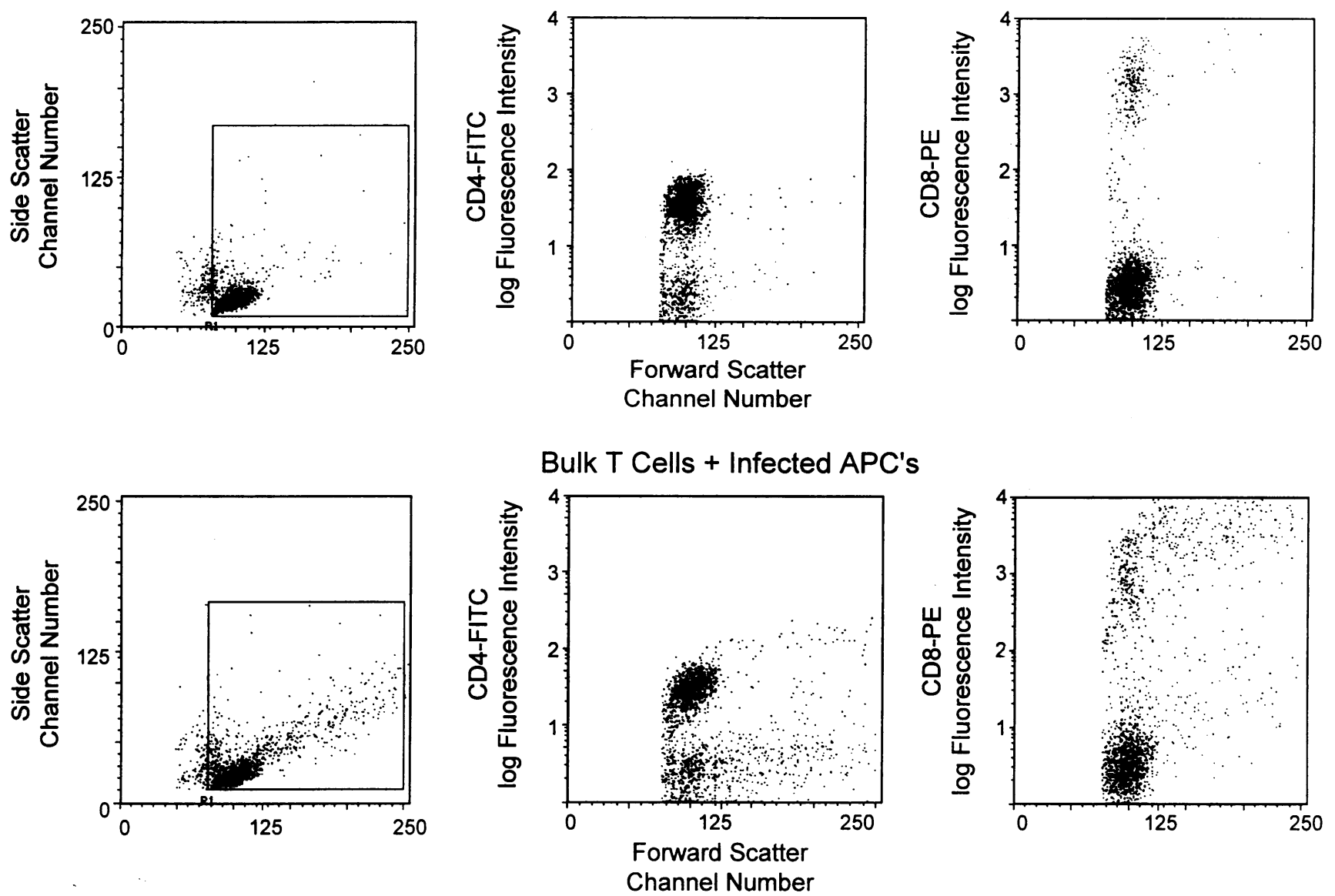

Figure 6. CD4/CD8 phenotype in bulk T cell populations responding to influenza virus antigens. Bulk T cells were cultured with uninfected or infected APCs for $7 \mathrm{~d}$, after which they were phenotyped for CD4 or CD8 expression as described in Methods. Dot plots are of forward versus side scatter (left), anti-CD4-FITC versus forward scatter (middle) or anti-CD8-PE versus forward scatter (right). Note that the majority of large cells responding to infected APCs are CD8+. Control mAbs did not stain the T cells (not shown).

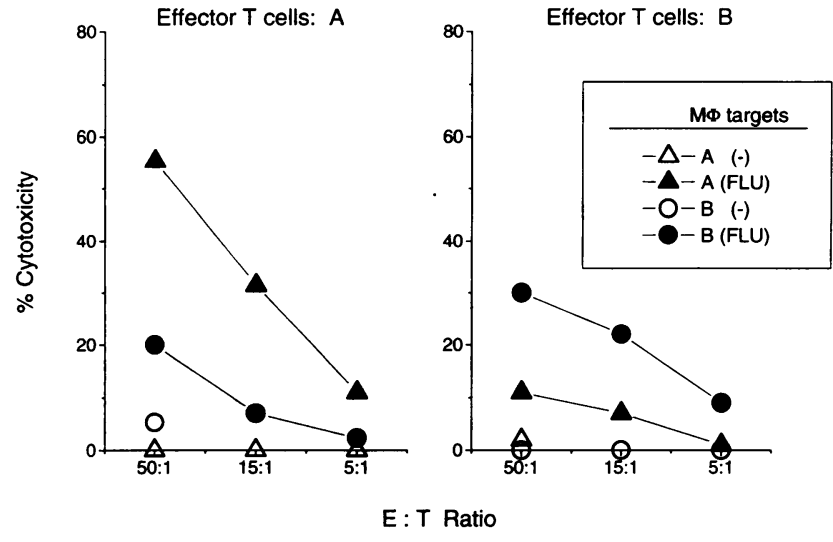

Figure 7. Evidence that human influenza-specific CTL are class I restricted. Donors A and B, who differ at class I but share class II antigens [DRw52, DQw1], served as sources of T cells and APCs. T cells were cultured with infected or uninfected syngeneic APCs for $7 \mathrm{~d}$, after which the cells were harvested for CTL activity. Lytic activity was measured on syngeneic and allogeneic macrophage targets. Uninfected APCs failed to elicit CTL activity (data not shown).
They are not ordinarily depleted in bulk culture systems and, therefore, could potentially mask specific CTL measurement.

$A P C$ requirements for the generation of influenza virusspecific CTLs. T cell-mediated immunity develops in two stages. In the afferent phase, dendritic cells bearing antigen initiate T-dependent responses from resting lymphocytes. Once activated, the sensitized $\mathrm{T}$ lymphoblasts can interact with other APCs in the efferent phase, to induce a number of effector functions, e.g., B cell antibody synthesis (37), macrophage activation, and IL-1 production (38). As demonstrated here with influenza virus, dendritic cells serve in a similar capacity to first induce the generation of CD8 + CTLs, which then acquire the ability to kill infected macrophage targets. These pathways for CTL generation are potentially important for the prevention of cell-cell spread of virus.

Several features may account for the observed differences between dendritic cells and monocytes in the induction of influenza-specific CTLs. One appears to be the manner in which influenza virus infection is handled by these two types of APCs. Greater than $90 \%$ of dendritic cells expressed HA, NP, (Fig. 1) and NS-1 (not shown) within $16 \mathrm{~h}$ and remained fully viable for $>24 \mathrm{~h}$ after infection. In sharp contrast, freshly isolated monocytes or week-old cultured macrophages were infected to 


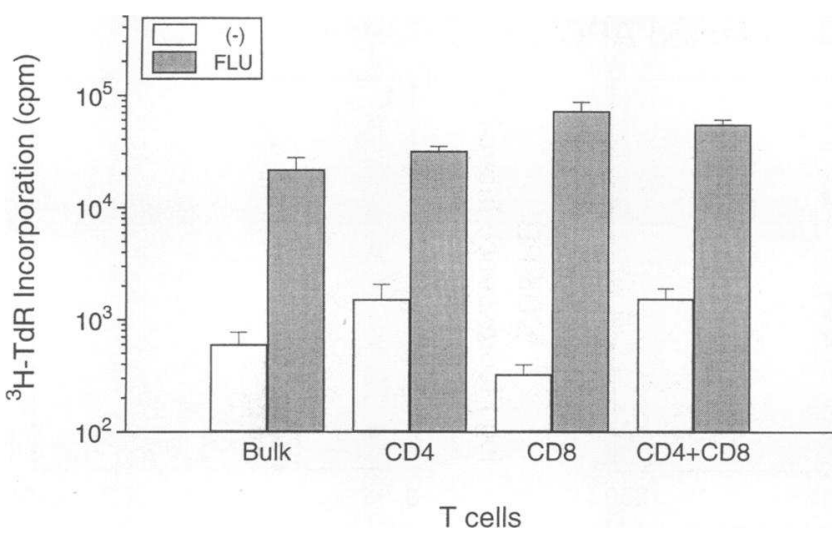

Figure 8. Purified CD4+ and CD8 $+\mathrm{T}$ cells proliferate to influenza virus-infected dendritic cells. CD4+ and CD8 $+\mathrm{T}$ cells were purified from a bulk $\mathrm{T}$ cell population to $>98 \%$ by staining with specific mAbs, followed by sorting on a FACStar Plus, as described in Methods. Bulk T cells, sorted CD4+, CD8+, and a combination of both sorted populations (CD4/CD8 cell ratio of 2:1) were tested in a standard proliferation assay for responsiveness to influenza virus-infected ER-, FcR- cells. The T/APC ratio was 5:1. Clear bars represent the responses to uninfected APCs whereas shaded bars represent the influenza virus-specific responses. Cultures were pulsed on day 5 for $12 \mathrm{~h}$ with $4 \mu \mathrm{Ci} / \mathrm{ml}$ of $\left[{ }^{3} \mathrm{H}\right] \mathrm{TdR}$. Results are means of triplicates \pm SD. Note the log scale on the $y$-axis.

a lesser extent $(<70 \%)$ but died within $16 \mathrm{~h}$ of infection (Fig. 1). In addition to influenza virus, dendritic cells are specialized APCs for the presentation of several other viruses to $\mathrm{T}$ cells, including HSV (30), Moloney leukemia virus (28), Sendai virus (28) in the mouse, and HIV in humans (39). It is not known whether the efficacy of dendritic cells in part reflects better developed pathways for the handling of viral antigens, e.g., efficient charging of MHC class I and II molecules. The findings nevertheless are consistent with other studies showing that dendritic cells present microbial antigens (M. tuberculosis [40], Leishmania [41], and staphylococcal enterotoxins [42]) efficiently to $\mathrm{T}$ cells.

Dendritic cells are also distinguished from APCs like monocytes and B cells in the efficiency with which they deliver signals to the TCR-CD3 complex on T cells. For example, occupancy of only $0.1 \%$ of dendritic cell surface class II molecules with superantigen is sufficient to induce $\mathrm{T}$ cell proliferation (23). This is due in part to the fact that dendritic cells express and upregulate many accessory molecules that are critical during the initiation of T cell immune responses (e.g., MLR [43] and superantigens [23]). They include B7/BB1 (CD80), ICAM-1 (CD54), and LFA-3 (CD58), ligands for CD28, CD11a, and CD2, respectively. Although we have yet to study the role of these accessory molecules on dendritic cells in CTL induction, there is evidence that interaction of $\mathrm{CD} 28$ with its ligand is a critical element in the activation of cytotoxic CD8+ $T$ cells (44). For example, murine class I restricted CTLs to alloantigens can be generated in the absence of help from CD4+ $T$ cells, provided a CD28-B7 interaction occurs in the induction phase (44). Furthermore, B7-transfected tumor cells can induce protective (CD8 + T cell-mediated) antitumor responses in vivo when CD4 $+\mathrm{T}$ cells are absent $(45,46)$. If dendritic cells are key accessories in CTL induction, one would predict that these APCs should be effective in the generation of CTL responses to other antigens (e.g., melanoma antigens, alloantigens) where $B 7$ is known to amplify the $T$ cell response $(43,45,46)$. The CD28-B7/BB1 interaction provides a critical costimulatory mechanism for IL-2 gene expression (47-49). This would explain the CD4 helper independence of CTL induction by dendritic cells, i.e., their ability to present antigen together with costimulatory molecules like B7/BB1 that enhance the production of IL-2.

Helper cells are not required for the generation of $\mathrm{CD} 8+$ CTLs. Resting human T cells extensively depleted of CD4+
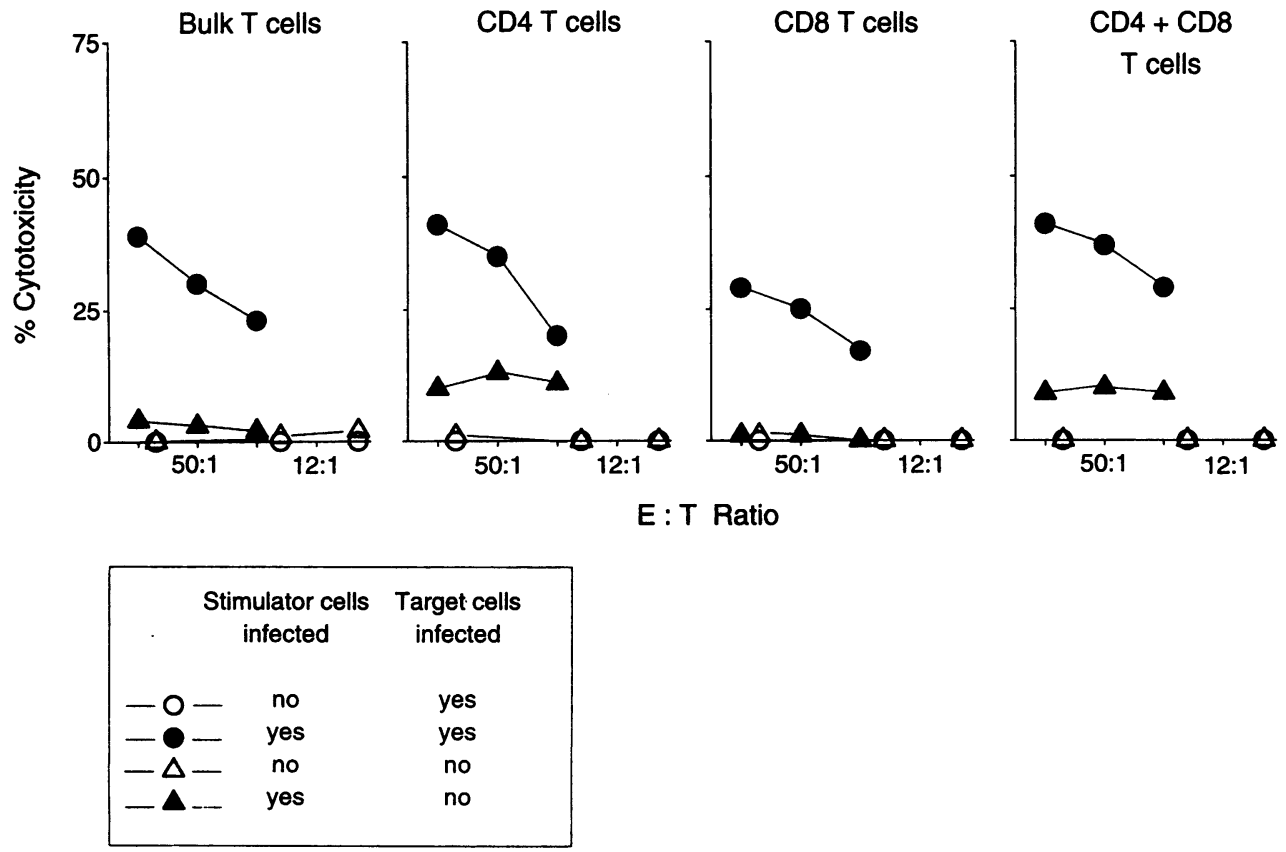

Figure 9. Dendritic cells stimulate the development of both CD4+ and CD8+ influenza virus-specific CTL. Bulk T cells and sorted purified CD4+ or CD8+ cells were stimulated with uninfected (open symbols) or infected (closed symbols) ER-, FcR - cells for 7 d. The T/APC ratio was 3:1. Cytolytic activity was measured on uninfected and infected syngeneic monocytes. CD4+ and CD8+ cells were also added together at a 2:1 ratio before the CTL assay (last panel on right). 
cells can be induced by dendritic cells to develop influenza virus-specific cytolytic activity. As in bulk cultures of $T$ cells, CTL activity is generated with relatively few dendritic cells (Fig. 9). Dendritic cells also directly induce human and murine CD8 + T cells to develop cytotoxic activity in the MLR $(8,50)$. In contrast to these findings, Nonacs et al. (26) found that mouse dendritic cells were unable to induce influenza virus-specific CTL activity in purified CD8 + $\mathrm{T}$ cells unless a source of CD4+ $\mathrm{T}$ cells or helper lymphokines was available. A key variable here may be the number of antigen-specific IL-2 producers in the primed $\mathrm{CD} 8+$ population. For example, the paucity of precursor $T$ cells in the mouse $(1: 16,600$ to $1: 2,400$ [51]) may be insufficient to generate enough lymphokine to amplify a CTL response. Also, far fewer murine dendritic cells $(<20 \%$, [26]) are capable of synthesizing viral proteins than human blood dendritic cells (>90\%, Fig. 1).

There are now several examples of CTL development in the apparent absence of CD4 help in vivo. For example, elimination of CD4 + $\mathrm{T}$ cells in mice does not ablate resistance to ectromelia virus (52), LCMV or vaccinia virus $(53)$, and tumors $(45,46)$.

Extensive proliferation of $C D 8+T$ cells in response to influenza virus-infected dendritic cells. The majority of $\mathrm{T}$ cells that proliferate to influenza virus antigens in bulk cultures are CD8+. We made this observation in routine FACS ${ }^{\circledR}$ analyses of stimulated cultures (Fig. 6), in which most enlarged $\mathrm{T}$ cells stained with antibodies to CD8. Primary populations of human $\mathrm{CD} 8+\mathrm{T}$ cells, depleted of CD4+ $\mathrm{T}$ cells, also proliferate extensively after exposure to influenza virus-infected dendritic cells. The proliferative responses were considerably greater when compared with bulk or CD4+ T cell responses (Fig. 8). Other than responses to MLR antigens (8), we are not aware of other systems where such extensive antigen-dependent CD8 blastogenesis takes place. In mice, after intraperitoneal infection with LCMV, large increases in CD8 $+\mathrm{T}$ cells occur in the spleen as well as the peritoneum (54).

Influenza virus-specific CD4+CTL are also generated by dendritic cells. Highly purified CD4+ cells can be induced by blood dendritic cells to proliferate and develop cytolytic activity (Figs. 8 and 9). However, it is necessary to remove the CD8+ $\mathrm{T}$ cells to observe both the blastogenesis and CTL responses. The reasons for this are unclear. We considered the possibility that, in bulk cultures, CD8 + CTLs might kill the CD4+ cells. Alternatively, there might be selective inhibition of exogenous antigen presentation via the class II pathway, as previously described for influenza virus-infected murine APCs (55). This seemed unlikely for two reasons. First, CD4+ T cells can respond directly to infected dendritic cells when separated from CD8 + T cells. Second, influenza virus-infected APCs could present PPD to $M$. tuberculosis-reactive CD4+ T cell clones as well as uninfected APCs (data not shown).

Influenza-specific CD4+ CTL have been described in both human and mouse systems $(16,31,32)$. In contrast to CD8+ CTLs, CD4+ class II-restricted CTLs lysed target cells treated with noninfectious influenza virus or purified HA preparations and class II presentation was sensitive to lysosomotropic agents (16). These differences provided critical early evidence that MHC class I- and class II-restricted CTL, depended upon divergent pathways for presentation of antigen. The role of CD4+ CTL in viral clearance and recovery from infection, however, remains to be determined. $\beta$-2-Microglobulin deficient $(-/-)$ mice have few CD8 $+\mathrm{T}$ cells but can clear vaccinia virus and nonlethal $\mathrm{HK} \times 31$ influenza $A$ virus and resist a low inoculation dose of PR8 (56), but recovery from lethal doses of the virulent strain seems to require the presence of CD8 $+\mathrm{T}$ cells (57). In contrast, $\beta$-2-microglobulin deficient $(-/-)$ mice infected with LCMV intracranially develop CD4+ CTL that mediate disease, similar to their CD8+ counterparts in infected normal strains (58).

Potential uses of CD8+CTLs in influenza prophylaxis and therapy. Influenza A virus infection remains a major cause of mortality and morbidity, primarily because the control of the respiratory illness has not been achieved through vaccination. Current vaccines are designed to boost antibody responses to viral antigens (HA and NA) that undergo antigenic drift and shift (10). Consequently, the protective effects of antibodies decline with time. Vaccines directed towards the induction of influenza virus-specific cytotoxic $T$ cell immune responses might be far more effective, because CTL have been shown to express cross-reactivity in recognition of subtypes of influenza A (18). There is evidence in humans that CTL responses play a role in recovery from infection. McMichael et al. (13) related levels of CTL immunity to clearance of nasal virus by normal donors inoculated with live virus. A clear association was observed between CTL responses and clearance of virus.

An ideal vaccine would use cross-reactive antigens, induce CD8 + CTL responses in most hosts, and have an efficient means of delivery. Several approaches to induce CTLs with these properties have been attempted in a number of systems. They include delivery of class I-restricted peptides with adjuvant (59-62), conjugated to lipid (63), complexed with immune-stimulating complexes (64), or inserted into liposomes $(65,66)$. The injection of DNA encoding the immunizing antigen directly into skeletal muscle (67) has also been reported to induce CTL.

Until recently, dendritic cells have not been directly considered in strategies to design new vaccines that generate CD8+ CTLs. Targeting antigen to dendritic cells has several advantages: one can maximize the efficiency of $T$ cell activation (9) and avoid anergy induction (68) or the use of adjuvants (69). For example, dendritic cells pulsed with antigen in vitro and delivered in vivo to mice have been highly effective for generating CD4+ immune responses to protein antigens and microbes $(69,70)$. Mouse dendritic cells pulsed with class I-restricted peptides of NP (26), HIV peptides (71), or given antigen via $\mathrm{pH}$-sensitive liposomes (66) into the cytoplasm can induce CTL responses.

A pivotal role for dendritic cells in human disease prophylaxis and therapy is suggested by their ability to directly induce strong CD8 + CTL responses, as shown here for influenza virus. It may be possible to pulse dendritic cells directly with NP peptides or with attenuated virus, for instance, and use these APCs in vivo to elicit CTL responses. By adapting the systems developed in this study, dendritic cells could also be used for generating large numbers of CD8 + CTL, for adoptive transfer to immunosuppressed individuals who are unable to mount normal immune responses. Immunotherapy with CD8 + CTL has been shown to amplify the immune response. Bone marrow transplant recipients given CMV-specific CTL by adoptive transfer do not develop disease or viremia (4). These novel approaches for immunoprophylaxis and therapy should be applicable to several situations where CD8 + CTLs are believed to play a therapeutic role, e.g., HIV infection (1-3), malaria (5), and malignancies such as melanoma $(6,7)$. 


\section{Acknowledgments}

We thank Dr. J. Yewdell for use of several reagents, Dr. A. Molloy for advice, S. Gezelter for assistance with sorting, J. Adams for graphics, and Dr. I. Tang for reviewing the manuscript.

This work was supported by grants from the National Institutes of Health (AR-39552 to N. Bhardwaj, AI-24775 to R. M. Steinman); the Irma T. Hirschl Trust (N. Bhardwaj); and the Deutsche Forschungsgemeinschaft (Be 1609/1-1) to A. Bender.

\section{References}

1. Koup, R. A., C. A. Pikora, K. Luzuriaga, D. B. Brettler, E. S. Day, G. P. Mazzara, and J. L. Sullivan. 1991. Limiting dilution analysis of cytotoxic T lymphocytes to human immunodeficiency virus gag antigens in infected persons. In vitro quantitation of effector cell populations with p17 and p24 specificities. J. Exp. Med. 174:1593-1600.

2. Carmichael, A., X. Jin, P. Sissons, and L. Borysiewicz. 1993. Quantitative analysis of the human HIV-1 specific cytotoxic $\mathrm{T}$ lymphocyte [CTL] response at different stages of HIV-1 infection. Differential CTL response to HIV-1 and Epstein-Barr virus in late disease. J. Exp. Med. 177:249-256.

3. Johnson, R. P., A. Trocha, T. M. Buchanan, and B. D. Walker. 1992. Identification of overlapping HLA class I-restricted cytotoxic $\mathrm{T}$ cell epitopes in a conserved region of the human immunodeficiency virus type 1 envelope glycoprotein. Definition of minimum epitopes and analysis of the effects of sequence variation. J. Exp. Med. 175:961-971.

4. Riddell, S. R., K. S. Watanabe, J. M. Goodrich, C. R. Li, M. E. Agha, and P. D. Greenberg. 1992. Restoration of viral immunity in immunodeficient humans by the adoptive transfer of T cell clones. Science (Wash. DC). 257:238-241.

5. Hill, A. V. S., J. Elvin, A. C. Willis, M. Aidoo, C. E. M. Allsopp, F. M. Gotch, X. M. Gao, M. Takiguchi, B. M. Greenwood, A. R. M. Townsend, et al. 1992. Molecular analysis of the association of HLA-B53 and resistance to severe malaria. Nature (Lond.). 360:434-439.

6. Van der Bruggen, P., C. Traversari, P. Chomez, C. Lurquin, E. De Plaen, B. Van Den Eynde, A. Knuth, and T. Boon. 1991. A gene encoding an antigen recognized by cytolytic T lymphocytes on a human melanoma. Science (Wash. DC). 254:1643-1647.

7. Brichard, V., A. Van Pel, T. Wolfel, C. Wolfel, E. De Plaen, B. Lethe', P. Coulie, and T. Boon. 1993. The tyrosinase gene codes for an antigen recognized by autologous cytolytic T lymphocytes on HLA-A2 melanomas. J. Exp. Med. 178:489-495.

8. Young, J. W., and R. M. Steinman. 1990. Dendritic cells stimulate primary human cytolytic lymphocyte responses in the absence of CD4+ helper T cells. $J$. Exp. Med. 171:1315-1332.

9. Steinman, R. M. 1991. The dendritic cell system and its role in immunogenicity. Annu. Rev. Immunol. 9:271-296.

10. Wiley, D. C., I. A. Wilson, and J. J. Skehel. 1981. Structural identification of the antibody-binding sites of Hong Kong influenza haemagglutinin and their involvement in antigenic variation. Nature (Lond.). 289:373-378.

11. Holt, P. G., M. A. Schon-Hegrad, and J. Oliver. 1987. MHC class II antigen-bearing dendritic cells in pulmonary tissues of the rat. Regulation of antigen presentation activity by endogenous macrophage populations. J. Exp. Med. 167:262-274.

12. Schon-Hegrad, M. A., J. Oliver, P. G. McMenamin, and P. G. Holt. 1991. Studies on the density, distribution, and surface phenotype of intraepithelial class II major histocompatability complex antigen [Ia]-bearing dendritic cells [DC] in the conducting airways. J. Exp. Med. 173:1345-1356.

13. McMichael, A. J., F. M. Gotch, G. R. Noble, and P. A. S. Beare. 1983. Cytotoxic T-cell immunity to influenza. N. Engl. J. Med. 309:13-17.

14. Townsend, A. R. M., F. M. Gotch, and J. Davey. 1985. Cytotoxic T cells recognize fragments of the influenza nucleoprotein. Cell. 42:457-467.

15. Townsend, A. R. M., J. Rothbard, F. M. Gotch, G. Bahadur, D. Wraith, and A. J. McMichael. 1986. The epitopes of influenza nucleoprotein recognized by cytotoxic $\mathrm{T}$ lymphocytes can be defined with short synthetic peptides. Cell. 44:959-968.

16. Morrison, L. A., A. E. Lukacher, V. L. Braciale, D. P. Fan, and T. J. Braciale. 1986. Differences in antigen presentation to MHC class I- and class II-restricted influenza virus-specific cytolytic T lymphocyte clones. J. Exp. Med. 163:903-921.

17. Carreno, B. M., R. W. Anderson, J. E. Coligan, and W. E. Biddison. 1990. HLA-B37 and HLA-A2.1 molecules bind largely nonoverlapping sets of peptides. Proc. Natl. Acad. Sci. USA. 87:3420-3424.

18. McMichael, A. J., and B. A. Askonas. 1978. Influenza virus-specific cytotoxic T cells in man: induction and properties of the cytotoxic cell. Eur. J. Immunol. 8:705-711.

19. Gotch, F., J. Rothbard, K. Howland, A. Townsend, and A. McMichael.
1987. Cytotoxic $\mathrm{T}$ lymphocytes recognize a fragment of influenza virus matrix protein in association with HLA-A2. Nature (Lond.). 326:881-882.

20. McMichael, A. J., F. M. Gotch, and J. Rothbard. 1986. HLA B37 determines an influenza A virus nucleoprotein epitope recognized by cytotoxic $\mathrm{T}$ lymphocytes. J. Exp. Med. 164:1397-1406.

21. Sutton, J., S. Rowland-Jones, W. Rosenberg, D. Nixon, F. Gotch, X.-M. Gao, N. Murray, A. Spoonas, P. Driscoll, M. Smith, et al. 1993. A sequence pattern for peptides presented to cytotoxic T lymphocytes by HLA B8 revealed by analysis of epitopes and eluted peptides. Eur. J. Immunol. 23:447-453.

22. Bowness, P., P. A. H. Moss, J. I. Bell, and A. J. McMichael. 1993. Conservation of T cell receptor usage by HLA B27-restricted influenza-specific cytotoxic $\mathrm{T}$ lymphocytes suggests a general pattern for antigen-specific major histocompatibility complex class I-restricted responses. Eur. J.' Immunol. 23:1417-1421.

23. Bhardwaj, N., J. W. Young, A. J. Nisanian, J. Baggers, and R. M. Steinman. 1993. Small amounts of superantigen, when presented on dendritic cells, are sufficient to initiate T cell responses. J. Exp. Med. 178:633-642.

24. Young, J. W., and R. M. Steinman. 1988. Accessory cell requirements for the mixed leukocyte reaction and polyclonal mitogens, as studied with a new technique for enriching blood dendritic cells. Cell. Immunol. 111:167-182.

25. Freudenthal, P. S., and R. M. Steinman. 1990. The distinct surface of human blood dendritic cells, as observed after an improved isolation method. Proc. Natl. Acad. Sci. USA. 87:7698-7702.

26. Nonacs, R., C. Humborg, J. P. Tam, and R. M. Steinman. 1992. Mechanisms of mouse spleen dendritic cell function in the generation of influenzaspecific, cytolytic T lymphocytes. J. Exp. Med. 176:519-529.

27. Young, J. W., and R. M. Steinman. 1987. Mononuclear phagocytes as targets for cytolytic T lymphocytes. J. Immunol. Methods. 100:99-105.

28. Kast, W. M., C. J. P. Boog, B. O. Roep, A. C. Voordouw, and C. J. M. Melief. 1988. Failure or success in the restoration of virus-specific cytotoxic $T$ lymphocyte response defects by dendritic cells. J. Immunol. 140:3186-3193.

29. Macatonia, S. E., P. M. Taylor, S. D. Knight, and B. A. Askonas. 1989. Primary stimulation by dendritic cells induces anti-viral proliferative and cytotoxic T cell responses in vitro. J. Exp. Med. 169:1255-1264.

30. Hengel, H., M. Lindner, H. Wagner, and K. Heeg. 1987. Frequency of herpes simplex virus-specific murine cytotoxic $\mathrm{T}$ lymphocyte precursors in mitogen-and antigen-driven primary in vitro T cell responses. J. Immunol. 139:41964202

31. Kaplan, D. R., R. Griffith, V. L. Braciale, and T. J. Braciale. 1984. Influenza virus-specific human cytotoxic $\mathrm{T}$ cell clones: heterogeneity in antigenic specificity and restriction by class II MHC products. Cell. Immunol. 88:193-206.

32. Cerundolo, V., A. G. D. Tse, R. D. Salter, P. Parham, and A. Townsend. 1991. CD8 independence and specificity of cytotoxic $T$ lymphocytes restricted by HLA-Aw68.1. Proc. R. Soc. Lond. B. 244:169-177.

33. Knight, S. C., and S. E. Macatonia. 1988. Dendritic cells and viruses. Immunol. Lett. 19:177-182.

34. Peschke, T., A. Bender, M. Nain, and D. Gemsa. 1993. Role of macrophage cytokines in influenza A virus infections. Immunobiology 189:340-355.

35. Fesq, H., M. Bacher, M. Nain, and D. Gemsa. 1994. Programmed cell death (apoptosis) in human monocytes infected by influenza virus. Immunobiology. 190:175-182.

36. O’Doherty, U., R. M. Steinman, M. Peng, P. U. Cameron, S. Gezelter, I. Kopeloff, W. J. Swiggard, M. Pope, and N. Bhardwaj. 1993. Dendritic cells freshly isolated from human blood express CD4 and mature into typical immunostimulatory dendritic cells after culture in monocyte-conditioned medium. J. Exp. Med. 178:1067-1078.

37. Inaba, K., and R. M. Steinman. 1985. Protein-specific helper T lymphocyte formation initiated by dendritic cells. Science (Wash. DC). 229:475-479.

38. Bhardwaj, N., L. L. Lau, S. M. Friedman, M. K. Crow, and R. M. Steinman. 1989. Interleukin 1 production during accessory cell-dependent mitogenesis of $\mathrm{T}$ lymphocytes. J. Exp. Med. 169:1121-1136.

39. Macatonia, S. E., S. Patterson, and S. C. Knight. 1991. Primary proliferative and cytotoxic $\mathrm{T}$ cell response to HIV induced in vitro by human dendritic cells. Immunology 74:399-406.

40. Pancholi, P., R. M. Steinman, and N. Bhardwaj. 1992. Dendritic cells efficiently immunoselect mycobacterial-reactive $\mathrm{T}$ cells in human blood, including clonable antigen-reactive precursors. Immunology 76:217-224.

41. Moll, H., H. Fuchs, C. Blank, and M. Röllinghoff. 1993. Langerhans cells transport Leishmania major from the infected skin to the draining lymph node for presentation to antigen-specific T cells. Eur. J. Immunol. 23:1595-1601.

42. Bhardwaj, N., S. M. Friedman, B. C. Cole, and A. J. Nisanian. 1992. Dendritic cells are potent antigen-presenting cells for microbial superantigens. $J$. Exp. Med. 175:267-273.

43. Young, J. W., L. Koulova, S. A. Soergel, E. A. Clark, R. M. Steinman, and B. Dupont. 1992. The B7/BB1 antigen provides one of several costimulatory signals for the activation of CD4 + T lymphocytes by human blood dendritic cells in vitro. J. Clin. Invest. 90:229-237.

44. Harding, F. A., and J. P. Allison. 1993. CD28-B7 interactions allow the 
induction of CD8+ cytotoxic T lymphocytes in the absence of exogenous help. J. Exp. Med. 177:1791-1796.

45. Townsend, S. E., and J. P. Allison. 1993. Tumor rejection after direct costimulation of CD8 + T cells by B7-transfected melanoma cells. Science (Wash DC). $259: 368-370$.

46. Chen, L., S. Ashe, W. A. Brady, I. Hellstrom, K. E. Hellstrom, J. A. Ledbetter, P. McGowan, and P. S. Linsley. 1992. Costimulation of antitumor immunity by the B7 counterreceptor for the T lymphocyte molecules CD28 and CTLA-4. Cell. 71:1093-1102.

47. Fraser, J. D., M. E. Newton, and A. Weiss. 1992. CD28 and T cell antigen receptor signal transduction coordinately regulate interleukin 2 gene expression in response to superantigen stimulation. J. Exp. Med. 175:1131-1134.

48. Fraser, J. D., B. A. Irving, G. R. Crabtree, and A. Weiss. 1991. Regulation of interleukin-2 gene enhancer activity by the T cell accessory molecule CD28. Science (Wash. DC). 251:313-316.

49. Thompson, C. B., T. Lindsten, J. A. Ledbetter, S. L. Kunkel, H. A. Young, S. G. Emerson, J. M. Leiden, and C. H. June. 1989. CD28 activation pathway regulates the production of multiple T cell-derived lymphokines/cytokines. Proc Natl. Acad. Sci. USA. 86:1333-1337.

50. Inaba, K., J. W. Young, and R. M. Steinman. 1987. Direct activation of CD8+ cytotoxic T lymphocytes by dendritic cells. J. Exp. Med. 166:182-194.

51. Wysocka, M., and J. P. Bennink. 1988. Limiting dilution analysis of memory cytotoxic $\mathrm{T}$ lymphocytes specific for individual influenza virus gene products. Cell. Immunol. 112:425-429.

52. Buller, M. L., K. L. Holmes, A. Hugin, T. N. Frederickson, and H. C. Morse III. 1987. Induction of cytotoxic T-cell response in vivo in the absence of CD4 helper cells. Nature (Lond.). 328:77-79.

53. Rahemtulla, A., W. P. Fung-Leung, M. W. Schilham, T. M. Kundig, S. R. Sambhara, A. Narendran, A. Arabian, A. Wakeham, C. J. Paige, R. M. Zinkernagel, et al. 1991. Normal development and function of CD8 + cells but markedly decreased helper cell activity in mice lacking CD4. Nature (Lond.). 353:180184.

54. Lynch, D. H., and R. E. Miller. 1994. Interleukin 7 promotes long-term in vitro growth of antitumor cytotoxic $\mathrm{T}$ lymphocytes with immunotherapeutic efficacy in vivo. J. Exp. Med. 179:31-42.

55. Domanico, S. Z., and S. K. Pierce. 1992. Virus infection blocks the processing and presentation of exogenous antigen with the major histocompatibility complex class II molecules. Eur. J. Immunol. 22:2055-2062.

56. Eichelberger, M., W. Allan, M. Zijlstra, R. Jaenisch, and P. C. Doherty. 1991. Clearance of influenza virus respiratory infection in mice lacking class major histocompatibility complex-restricted CD8+ T cells. J. Exp. Med. 174:875880 .

57. Bender, B. S., T. Croghan, L. Zhang, and P. A. Small, Jr. 1992. Transgenic mice lacking class I major histocompatibility complex-restricted $\mathrm{T}$ cells have delayed viral clearance and increased mortality after influenza virus challenge. $J$. Exp. Med. 175:1143-1145.

58. Muller, D., B. H. Koller, J. L. Whitton, K. E. LaPan, K. K. Brigman, and J. A. Frelinger. 1992. LCMV-specific, class II-restricted cytotoxic T cells in $\beta_{2}$ microglobulin-deficient mice. Science (Wash. DC). 255:1576-1578.

59. Kuzu, H., Y. Kuzu, H. Zaghouani, and C. Bona. 1993. In vivo priming effect during various stages of ontogeny of an influenza $\mathrm{A}$ virus nucleoprotein peptide. Eur. J. Immunol. 23:1397-1400.

60. Aichele, P., H. Hengartner, R. M. Zinkernagel, and M. Schulz. 1990. Antiviral cytotoxic $\mathrm{T}$ cell response induced by in vivo priming with a free synthetic peptide. J. Exp. Med. 171:1815-1820.

61. Gao, X.-M., B. Zheng, F. Y. Liew, S. Brett, and J. Tite. 1991. Priming of influenza virus-specific cytotoxic $\mathrm{T}$ lymphocytes vivo by short synthetic peptides. J. Immunol. 147:3268-3273.

62. Schulz, M., R. M. Zinkernagel, and H. Hengartner. 1991. Peptide-induced antiviral protection by cytotoxic T cells. Proc. Natl. Acad. Sci. USA. 88:991993.

63. Deres, K., H. Schild, K.-H. Wiesmuller, G. Jung, and H.-G. Rammensee. 1989. In vivo priming of virus-specific cytotoxic $\mathrm{T}$ lymphocytes with synthetic lipopeptide vaccine. Nature (Lond.). 342:561-564.

64. Takahashi, H., T. Takeshita, B. Morein, S. Putney, R. N. Germain, and J. A. Berzofsky. 1990. Induction of CD8+ cytotoxic T cells by immunization with purified HIV-1 envelope protein in ISCOMs. Nature (Lond.). 344:873-875.

65. Watari, E., B. Dietzschold, G. Szokan, and E. Heber-Katz. 1987. A synthetic peptide induces long-term protection from lethal infection with herpes simplex virus 2. J. Exp. Med. 165:459-470.

66. Nair, S., F. Zhou, R. Reddy, L. Huang, and B. T. Rouse. 1992. Soluble proteins delivered to dendritic cells via $\mathrm{pH}$-sensitive liposomes induce primary cytotoxic T lymphocyte responses in vitro. J. Exp. Med. 175:609-612.

67. Ulmer, J. B., J. J. Donnelly, S. E. Parker, G. H. Rhodes, P. L. Felgner, V. J. Dwarki, S. H. Gromkowski, R. R. Deck, C. M. DeWitt, A. Friedman, et al. 1993. Heterologous protection against influenza by injection of DNA encoding a viral protein. Science (Wash. DC). 259:1745-1749.

68. Fuchs, E. J., and P. Matzinger. 1992. B cells turn off virgin but not memory T cells. Science (Wash. DC). 258:1156-1159.

69. Inaba, K., J. P. Metlay, M. T. Crowley, and R. M. Steinman. 1990. Dendritic cells pulsed with protein antigens in vitro can prime antigen-specific, MHC-restricted T cells in situ. J. Exp. Med. 172:631-640.

70. Inaba, K., M. Inaba, M. Naito, and R. M. Steinman. 1993. Dendritic cell progenitors phagocytose particulates, including Bacillus Calmette-Guerin organisms, and sensitize mice to mycobacterial antigens in vivo. J. Exp. Med. 178:479488.

71. Takahashi, H., Y. Nakagawa, K. Yokomuro, and J. A. Berzofsky. 1993. Induction of $\mathrm{CD} 8+$ cytotoxic $\mathrm{T}$ lymphocytes by immunization with syngeneic irradiated HIV-1 envelope derived peptide-pulsed dendritic cells. Int. Immunol. 5:849-857. 